\title{
Effect of oral magnesium supplementation on serum magnesium levels in children recovering from severe acute malnutrition
}

\author{
*B Dakshayani ${ }^{1}$, A V Keshav Murthy ${ }^{1}$, Mallesh Kariyappa ${ }^{1}$
}

Sri Lanka Journal of Child Health, 2021; 50(1): 22-27

\begin{abstract}
Introduction: Children with severe acute malnutrition (SAM) have increased requirements for magnesium during recovery. World Health Organization recommends routine use of magnesium supplements in children with SAM. But, there is scanty knowledge about the effect of oral supplementation of magnesium sulphate on serum magnesium levels in children with SAM.
\end{abstract}

Objectives: To estimate the levels of serum magnesium in SAM children on admission, in transition phase and on discharge.

Method: Prospective observational study, measuring serum magnesium levels on admission, in transition phase and on discharge, in 1-59 month old children admitted with SAM and treated as per national guidelines. Fifty percent magnesium sulphate was given at $0.3 \mathrm{ml} / \mathrm{kg} /$ day for 14 days.

Results: Of the 43 children studied, mean age was $11.54 \pm 7.90$ months. The mean serum magnesium level was $2.49 \pm 0.55 \mathrm{mg} / \mathrm{dl}$ at admission, $2.34 \pm 0.48 \mathrm{mg} / \mathrm{dl}$ at transition phase, and 2.36 $\pm 0.47 \mathrm{mg} / \mathrm{dl}$ at discharge. The decrease in mean serum magnesium at transition phase was not significant when compared to admission. Also the mean serum magnesium at discharge was not significantly decreased when compared to admission. Only one child had asymptomatic hypomagnesaemia at admission which recovered during treatment. $28(65 \%)$ children responded well by gaining weight and the remaining 15 (35\%) children did not respond. The study group had an average weight gain of $7.23 \pm 4.82$ per $\mathrm{kg}$ per day.

Conclusions: The mean serum magnesium levels at admission, during transition and at discharge

\section{${ }^{1}$ Bangalore Medical College and Research Institute, Karnataka, India \\ *Correspondence: dakshayani.sreeraghu@gmail.com}

(iD) https://orcid.org/0000-0003-4238-3006

(Received on 24 January 2020: Accepted after revision on 20 March 2020)

The authors declare that there are no conflicts of interest

No funding was used for the project.

Open Access Article published under the Creative

Commons Attribution CC-BY (C) (i) License were within the normal range in children with SAM when supplemented with 50\% magnesium sulphate as per national guidelines.

DOI: http://dx.doi.org/10.4038/sljch.v50i1.9396

(Key words: severe acute malnutrition, serum magnesium, oral magnesium sulphate supplementation)

\section{Introduction}

Nutritional factors contribute to around $45 \%$ deaths in under-5 year old children ${ }^{1}$. Deficiency of magnesium is common in children with severe acute malnutrition $(\mathrm{SAM})^{2}$. Hypomagnesaemia is known to increase mortality in children with $\mathrm{SAM}^{3}$. Magnesium deficiency in malnourished children can be asymptomatic or can produce symptoms like loss of appetite, muscular weakness, lethargy, weight loss, tremor, seizures and psychomotor changes ${ }^{4}$. Magnesium therapy in SAM aids recovery and decreases the case fatality rate $^{5}$. World Health Organisation (WHO) ${ }^{6}$ and national guidelines ${ }^{7}$ recommend the routine use of magnesium supplementation in children with SAM. Magnesium is supplemented in the form of 1) oral $50 \%$ magnesium sulphate solution or 2) in the form of standard mineral mix, used for local preparation of Formula 75 and Formula100 or 3) a pre-mix (Formula 75 and Formula 100) fortified with magnesium. Both standard mineral mix and premix (Formula 75 and Formula100) are effective in improving serum magnesium levels in malnourished children ${ }^{8,9,10}$. However, they are not available in India. In India, magnesium is supplemented as $50 \%$ magnesium sulphate (intramuscular on day 1 , and then orally for 14 days). Previous study ${ }^{11}$ on efficacy of oral magnesium supplementation in SAM children was not conclusive due to high loss of follow up. Although concentration of serum magnesium might not sufficiently reflect body status, low levels can still indicate inadequate intake. Hence our aim was to assess the efficacy of oral magnesium supplementation by estimating serum magnesium levels during nutritional rehabilitation of SAM children.

\section{Objectives}

To estimate the levels of serum magnesium in SAM children on admission, in transition phase and on discharge. 


\section{Method}

A prospective observational cohort study was carried out in the nutritional rehabilitation centre attached to a tertiary care hospital from April to September 2019. SAM children admitted to Nutritional Rehabilitation Centre (NRC), aged between one month and 5 years, were enrolled in the study. SAM children with any underlying chronic illness as secondary cause of malnutrition were excluded from the study.

Anthropometry and clinical assessment were performed on admission. Body weight was measured to the nearest $10 \mathrm{~g}$ utilising an electronic paediatric scale (Salter weighing machine). The recumbent length, to the nearest $0.1 \mathrm{~cm}$ was measured using an infantometer for children 2 years old or younger. For children over 2 years old or longer than $87 \mathrm{~cm}$, standing height was measured to the nearest $0.1 \mathrm{~cm}$, utilising a stadiometer. Anthropometric Z-scores, based on the 2006 WHO child growth standards, were calculated. Mid upper arm circumference (MUAC) was measured to the nearest $0.1 \mathrm{~cm}$ utilising a MUAC tape. Presence of bilateral pitting oedema was assessed by applying gentle pressure with the thumb for 10 seconds to the dorsal surface of both feet on admission.

Serum magnesium was measured at three time points during the children's stay in hospital - on admission, just before transition to F100 (end of stabilisation phase), and on discharge, in all children. At each time point, $1 \mathrm{ml}$ of blood was taken into a vacutainer and centrifuged using Beckman Coulter $\mathrm{Au}$ 480, and serum magnesium was estimated by the photometer method. According to the laboratory reference values and Nelson Textbook of Paediatrics ${ }^{12}$, we defined normal plasma magnesium concentration as 1.5-2.3 $\mathrm{mg} / \mathrm{dl}$. After enrolment, all children were managed according to national SAM guidelines ${ }^{7}$. Children were given formula 75 diet on admission. Magnesium was supplemented as $0.3 \mathrm{ml} / \mathrm{kg} /$ day of $50 \%$ magnesium sulphate $(0.6 \mathrm{mmol} / \mathrm{kg} / \mathrm{day})$ for 14 days. It was given intramuscularly on day 1 and then orally diluted with feeds. After stabilization, children were given formula 100 in transition and rehabilitation phases and home based diet before discharge during rehabilitation phase.

Demographic features, clinical features, laboratory investigations, treatment aspects and outcome were recorded in a pretested proforma. The outcome indicators were defined as follows:

- Recovered - weight gain of more than $5 \mathrm{~g} / \mathrm{kg} /$ day on three consecutive days or $15 \%$ weight gain from base line before discharge.
- Non responder - no weight gain after completing treatment.

- $\quad$ Average weight gain (g/kg/day) Maximum weight in $\mathrm{kg}$ at discharge minimum weight in $\mathrm{kg} x 1000$ divided by minimum weight $\times$ No. of days between minimum weight to maximum weight

- Time for stabilization - The criteria for stabilization was according to WHO guidelines: Absence of any danger or emergency signs, decreasing oedema, tolerating and completing full prescribed volume of F75 feeds.

- Time to discharge - number of days taken to achieve a weight gain of $5 \mathrm{~g} / \mathrm{kg} /$ day on three consecutive days

Based on a previous study by Madhusudan $\mathrm{K}$, et al, as serum magnesium increased by $0.2 \%$ from admission to discharge, and an alpha error of $5 \%$ and a power of 80 we arrived at a sample size of 40. As we had also planned to do serum calcium simultaneously, the sample size for serum calcium was estimated as 43 , based on previous studies. Hence we decided to enrol 43 patients.

Ethical issues: Ethics Clearance was obtained from the Bangalore Medical College and Research Institute, Karnataka, India (ERC No. BMC/PGs/289/2017-178) and written informed consent from the parents of participating children

Statistical analysis: The data collected were entered into the Microsoft Excel sheet and analysed using SPSS version 20.0. Baseline data were presented using descriptive statistics namely mean, standard deviation, percentage. Independent t-test was used to determine significant difference between two groups and dependent t-test was used to determine significant difference between preand post-data, Chi Square test was used to determine association between qualitative variables.

\section{Results}

All 214 children admitted to Nutritional Rehabilitation Centre (NRC) during the study period were screened for eligibility. About 145 children were excluded as they did not meet inclusion criteria (spastic cerebral palsy, global developmental delay, congenital heart disease, renal disorders, postoperative surgical conditions, only on mother's milk etc.). Among remaining 69 children, 19 declined to participate. Remaining 50 children were enrolled on admission. But 4 were discharged early and only 46 were examined at transition phase. On discharge, as we could not get serum magnesium in 3 patients only 43 were examined. The flow chart of the participants in the study is shown in Figure 1. 


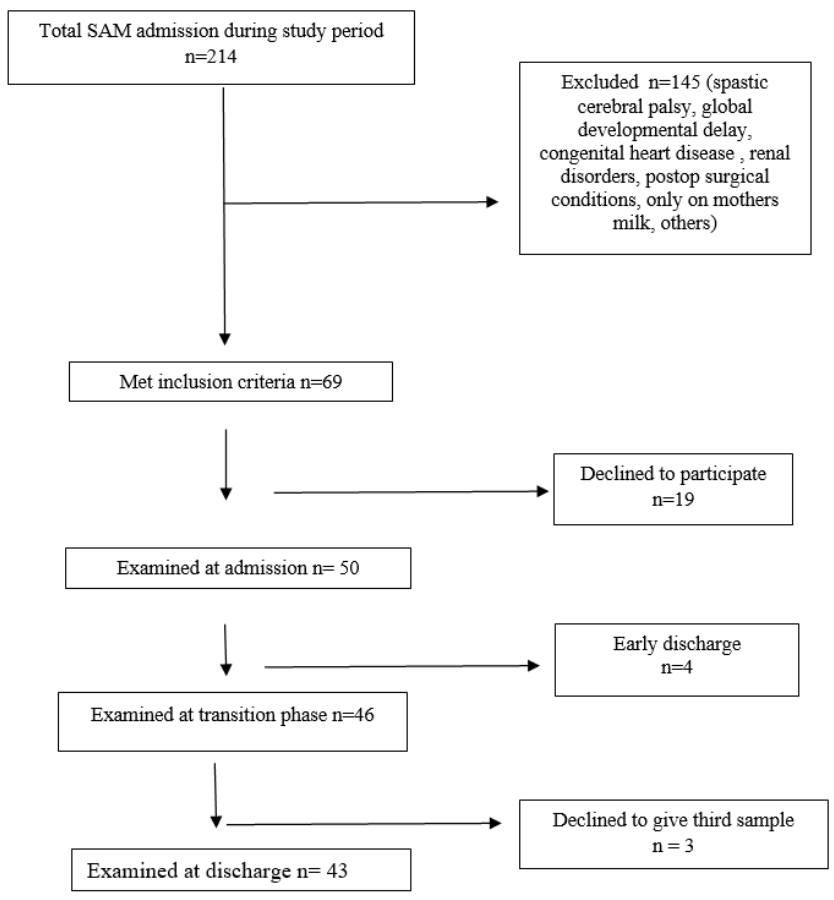

Figure 1: Flow chart of study participants

The mean age on admission (Mean \pm SD) was $11.54 \pm 7.90$ months. The mean weight on admission was $5.12 \pm 1.68 \mathrm{~kg}$ which increased significantly to $5.32 \pm 1.66 \mathrm{~kg}$ on discharge $(\mathrm{p}=0.0001)$. The mean height was $64.77 \pm 9.80 \mathrm{~cm}$ on admission and $64.79 \pm 9.82 \mathrm{~cm}$ on discharge $(\mathrm{p}=0.323)$. The mean mid upper arm circumference (MUAC) was $9.77 \pm 2.47 \mathrm{~cm}$ on admission and $9.92 \pm 2.06 \mathrm{~cm}$ on discharge $(p=0.521)$. The baseline data of study population on admission are shown in Table 1.

The mean serum magnesium level was $2.49 \pm 0.55$ $\mathrm{mg} / \mathrm{dl}$ on admission, $2.34 \pm 0.48 \mathrm{mg} / \mathrm{dl}$ in the transition phase and $2.36 \pm 0.47 \mathrm{mg} / \mathrm{dl}$ on discharge (Figure 2).

Table 1: Baseline data of the study population on admission $n=43$

\begin{tabular}{|l|c|}
\hline \multicolumn{1}{|c|}{ Parameter } & Number (\%) \\
\hline Age & \\
$\leq 6$ Months & $11(25.6)$ \\
6 months to 5 years & $32(74.4)$ \\
\hline Gender & \\
Male & $24(55.8)$ \\
Female & $19(44.2)$ \\
\hline Maturity & \\
Term & $36(83.7)$ \\
Preterm & $07(16.3)$ \\
\hline Low birth weight & $19(44.2)$ \\
\hline Neonatal intensive care unit graduate & $15(34.9)$ \\
\hline Feeding & $25(58.2)$ \\
Exclusively breast fed for 6 months & $24(55.8)$ \\
Top fed & $25(58.2)$ \\
Complementary feeding started at 6 months & $43(100.0)$ \\
\hline Weight for length criteria (<3SD) & $27(62.8)$ \\
\hline Mid upper arm circumference criteria $(<11.5)$ & $01(02.3)$ \\
\hline Pitting oedema & \\
\hline Comorbid condition (multiple) & $21(48.8)$ \\
Anaemia & $13(30.2)$ \\
Pneumonia & $13(30.2)$ \\
Diarrhoea & $04(09.3)$ \\
Sepsis & $13(30.3)$ \\
Other & \\
\hline
\end{tabular}




\section{Serum Magnesium Levels at Different Phases}

2.55

2.45

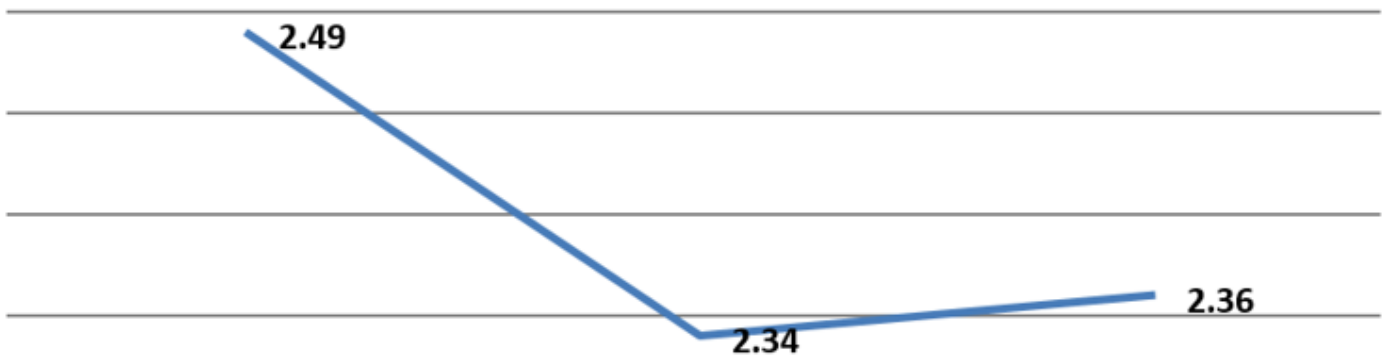

2.3

At Admission

At Transition Phase

At Discharge

Figure 2: Mean serum magnesium at different phases of nutritional rehabilitation

The decrease in mean serum magnesium at transition phase was not significant when compared discharge was not significantly decreased when to admission. Also the mean serum magnesium at compared to admission (Table 2).

Table 2: Comparison of serum magnesium (mg/dl) among study participants at various phases of the study

\begin{tabular}{|l|c|c|c|}
\hline \multicolumn{1}{|c|}{ Serum magnesium } & Mean & Standard deviation & p-value \\
\hline At admission & 2.49 & 0.55 & \multirow{2}{*}{0.083} \\
\cline { 1 - 3 } At transition phase & 2.34 & 0.48 & \\
\hline & & & \multirow{2}{*}{0.082} \\
\hline At admission & 2.49 & 0.55 & \\
\hline
\end{tabular}

Only one child had hypomagnesaemia at admission which was asymptomatic and resolved with treatment. Among the 43 children in the study group, $28(65.1 \%)$ responded well by gaining weight and the remaining $15(34.9 \%)$ did not respond. There was no difference in mean serum magnesium levels at admission between non responders $(2.42 \pm 0.51 \mathrm{mg} / \mathrm{dl})$ and responders $(2.54 \pm 0.44 \mathrm{mg} / \mathrm{dl})$. There was no difference in mean serum magnesium levels at transition phase between non responders $(2.4 \pm 0.7 \mathrm{mg} / \mathrm{dl})$ and responders $(2.31 \pm 0.3 \mathrm{mg} / \mathrm{dl})$. The mean serum magnesium at discharge was significantly more $(\mathrm{p}=0.02)$ in non-responders $(2.55 \pm 0.64 \mathrm{mg} / \mathrm{dl})$ when compared to responders $(2.26 \pm 0.32 \mathrm{mg} / \mathrm{dl})$. The study group had an average weight gain of 7.23 \pm 4.82 per $\mathrm{kg}$ per day. The mean duration of stabilization phase (time for stabilization) was $4.81 \pm 0.96$ days and the mean duration of stay (time to discharge) was $13.40 \pm 2.61$ days (Table 3 ).

Table 3: Distribution of outcome among study participants $(n=43)$

\begin{tabular}{|l|c|}
\hline \multicolumn{1}{|c|}{ Outcome indicator } & Result \\
\hline Recovered $\mathrm{n}(\%)$ & $28(65.1)$ \\
\hline Non-responder $\mathrm{n}(\%)$ & $15(34.9)$ \\
\hline Average weight gain $(\mathrm{g} / \mathrm{kg} /$ day) Mean \pm SD & $7.23 \pm 4.82$ \\
\hline Duration of stabilization phase (in days) Mean \pm SD & $4.81 \pm 0.96$ \\
\hline Duration of stay (in days) Mean \pm SD & $13.40 \pm 2.61$ \\
\hline
\end{tabular}

\section{Discussion}

In our study the mean serum magnesium at admission was $2.49 \pm 0.55 \mathrm{mg} / \mathrm{dl}$ which is similar to Madhusudan $\mathrm{K}$, et $a l^{11}$. Others have reported lesser values (Zafar et al $1.11 \pm 0.24 \mathrm{mg} / \mathrm{dl})^{13}$. The lower values of serum magnesium in other studies could be due to variation in dietary intake of the study population. After supplementation with 
$0.6 \mathrm{mmol} / \mathrm{kg} /$ day of magnesium orally, as $50 \%$ magnesium sulphate, serum magnesium decreased to $2.34 \pm 0.48 \mathrm{mg} / \mathrm{dl}$ at start of the transition phase in our study. Similarly, Mbethe et $a l^{14}$ have reported a serum magnesium of $2.45 \pm 0.82 \mathrm{mg} / \mathrm{dl}$ at admission which decreased to $2.31 \pm 0.65 \mathrm{mg} / \mathrm{dl}$ on day 5 despite supplementing with magnesium sulphate $0.4-0.6 \mathrm{mmol} / \mathrm{kg} /$ day orally. They have also reported that about $15 \%$ children developed refeeding syndrome on day 5 and that serum magnesium was significantly lower in the refeeding syndrome group when compared to those without re-feeding syndrome on day 5 .

In our study the mean serum magnesium was $2.49 \pm 0.55 \mathrm{mg} / \mathrm{dl}$ at admission and $2.36 \pm 0.47 \mathrm{mg} / \mathrm{dl}$ at discharge after supplementing with $0.3 \mathrm{ml} / \mathrm{kg}$ of $50 \% \mathrm{MgSO} 4$ for 14 days. Madhusudan $\mathrm{K}$, et $a l^{11}$ have reported a serum magnesium of $2.4 \pm 0.5 \mathrm{mg} / \mathrm{dl}$ at admission which increased to $2.6 \pm 0.4 \mathrm{mg} / \mathrm{dl}$ after supplementing with $0.3 \mathrm{ml} / \mathrm{kg}$ of $50 \% \mathrm{MgSO} 4$ for 14 days. Madhusudan $\mathrm{K}$ has reported higher serum magnesium value at discharge when compared to our study probably because of $30 \%$ loss of follow up at discharge (including all three with hypomagnesaemia) in their study. Khalil et al have reported a serum magnesium of $1.36 \pm 0.25 \mathrm{mg} / \mathrm{dl}$ at admission which increased to $2.06 \pm 0.35 \mathrm{mg} / \mathrm{dl}$ after supplementing with combined mineral vitamin mix which provides $0.3-0.6 \mathrm{mmol} / \mathrm{kg} / \mathrm{day}$ of magnesium. They have also reported better weight gain in magnesium supplemented group. Hence we can understand that a magnesium supplementation of $0.3-0.6 \mathrm{mmol} / \mathrm{kg} /$ day either by combined mineral vitamin mix or by $50 \%$ magnesium sulphate is enough to maintain serum magnesium values and weight gain.

On the other hand, Hother et $a l^{10}$ have treated children with pre-mixed F-75 and F-100 (Nutriset, Malaunay, France), containing $85 \mathrm{mg} / 1$ (3.49 $\mathrm{mmol} / \mathrm{l})$ and $154 \mathrm{mg} / \mathrm{L}(6.32 \mathrm{mmol} / \mathrm{l})$ of magnesium respectively. This amounts to an intake of $0.44 \mathrm{mmol} / \mathrm{kg} /$ day during $\mathrm{F} 75$ and 0.94 to $1.39 \mathrm{mmol} / \mathrm{kg} /$ day during F100 therapy. Hother et al have reported a mean serum magnesium of $2.31 \pm 0.55 \mathrm{mg} / \mathrm{dl}$ at admission, which increased by $0.51 \mathrm{mg} / \mathrm{dl}$ during transition and became $2.74 \pm$ $0.41 \mathrm{mg} / \mathrm{dl}$ at discharge. At discharge, majority had serum magnesium level above the normal range. Hence premix F75 and F100 are also effective in improving serum magnesium levels in SAM children. In our study, hypomagnesaemia was found in $1(2.3 \%)$ child. The frequency of hypomagnesemia at admission has been reported as $36 \%$ by Karakelleoglu C et $a l^{3}, 13 \%$ by Hother et $a l^{10}, 3.2 \%$ by Madhusudan $\mathrm{K}$, et $a l^{11}$. This discrepancy can be due to variation in dietary intake of magnesium in the study population. The hypomagnesaemia in one child in our study was asymptomatic and improved with magnesium supplementation. Karakelleoglu $\mathrm{C}$, et $a l^{3}$ have reported that mortality was 7.5 times higher in the malnourished children with hypomagnesaemia than in the malnourished children without hypomagnesaemia.

Majority of children in our study responded with good weight gain. The higher serum magnesium at discharge in non-responders shows that magnesium was not a limiting factor in growth. The importance of supplementing malnourished children with magnesium has been appreciated for many years, due to its importance to lean tissue accretion, as well as for homeostasis of potassium, calcium and other nutrients. Ideally, evaluation of the adequacy of magnesium supplementation would require a trial of different doses, and with measurement of urinary excretion and growth.

The strength of our study is that this is one of the first studies to describe the levels of serum magnesium at different phases of nutritional rehabilitation of SAM children receiving oral magnesium sulphate supplementation. In addition, there was no loss of follow up in the three points of time at which serum magnesium was done. The limitations include observational design and modest sample size.

\section{Conclusions}

Mean serum magnesium levels at admission, during transition and at discharge were well within the normal range in severe acute malnourished children when supplemented with 50\% magnesium sulphate as per national / WHO guidelines. We conclude that oral magnesium supplementation as per WHO /national guidelines during treatment of severe acute malnourished children is adequate.

\section{References}

1. United Nations Interagency Group for Child Mortality Estimation. Levels and trends in child mortality. Report 2019. New York, United Nations Children's Fund, 2019.

2. Alleyne GA, Halliday D, Waterlow JC, Nichols BL. Chemical composition of Organs of children who died from malnutrition. British Journal of Nutrition 1969; 23:783-90.

https://doi.org/10.1079/BJN19690089

PMid: 5357045

3. Karakelleoglu C, Orbak Z, Ozturk F, Kosan C. Hypomagnesaemia as a mortality risk factor in proteinenergy malnutrition. Journal of Health, 
Population and Nutrition 2011; 29(2): 181-2. https://doi.org/10.3329/jhpn.v29i2.7863 PMid: 21608429 PMCid: PMC3126992

4. Singla PN, Chand P, Kumar A, Kachhawaha JS. Serum magnesium levels in proteinenergy malnutrition. Journal of Tropical Pediatrics 1998; 44(2):117-9.

https://doi.org/10.1093/tropej/44.2.117

PMid: 9604603

5. Caddell JL. Magnesium in the therapy of protein-calorie malnutrition of childhood. Journal of Pediatrics 1965; 66:392-413. https://doi.org/10.1016/S00223476(65)80 197-4

6. World Health Organization. WHO pocket book of hospital care for children: guidelines for the management of common illnesses with limited resources. Geneva: World Health Organization, second edition 2013. 206 p.

7. Operational Guidelines on Facility Based Management of Children with Severe Acute Malnutrition Ministry of Health and Family Welfare Government of India, 2011. Accessed from: https:/www.nhm.gov.in/images/pdf/progr ammes/childhealth/guidelines/operational _guidelines_on_fbmc_with_sam.pdf.

8. Al Baki A, Motiur Rahman AZM, Islam Khan S, Rabbany A, Shultana K, Chowdhury D, et al. Clinical improvement after oral magnesium supplementation in children with severe acute malnutrition - An observational study. American Journal of Pediatrics 2019; 5(4): 209-13.

9. Khalil MI, Baki AA, Akhter N, Azad MASA, Zafreen F, Wahab MA. Magnesium supplementation on children with severe protein energy malnutrition. Journal of Armed Forces Medical College, Bangladesh 2008; 4(2): 10-3. https://doi.org/10.3329/jafmc.v4i2.1821
10. Hother AL, Girma T, Rytter MJ, Abdissa A, Ritz C, Mølgaard C et al. Serum phosphate and magnesium in children recovering from se vere acute undernutrition in Ethiopia:

an observational study. $B M C$ Pediatrics 2016; 16(1):178. https://doi.org/10.1186/s12887-016-07129

PMid: 27814707 PMCid: PMC5097423

11. Madhusudhan K, Rajeev PK, Shireesha A, Ushashree GV. Study of risk factors of severe acute malnutrition (SAM) in children 6 months to 5 years of age and evaluation of effect of micronutrient supplementation (WHO protocol) on serum zinc and magnesium levels: a case control study. International Journal of Contemporary Pediatrics 2017; 4:1198205.

https://doi.org/10.18203/23493291.ijcp20 172112

12. Kliegman RM, Stanton BF, St Geme J W, Schor NF. Nelson Textbook of Paediatrics, 20th ed. Saunders, Philadelphia, 2016.

13. Zafar S, Butt A, Ayesha H, Malik BA. Serum magnesium level; comparison between healthy and malnourished children. Professional Medical Journal 2010; 17(2):279-85.

14. Mbethe AP, Mda S. Incidence of Refeeding Syndrome and its associated factors in South African children hospitalized with severe acute malnutrition, Iranian Journal of Pediatrics 2017; 27(3):e8297. https://doi.org/10.5812/ijp.8297 